\title{
Hanford Site Cleanup and Transition: Risk Data Needs for Decision Making (Hanford Risk Data Gap Analysis) Decision Guide
}

SW Gajewski

GR Bilyard

CS Glantz
BL Harper

PL Miller

October 1995

Prepared for the U.S. Department of Energy under Contract DE-AC06-76RLO 1830

Pacific Northwest Laboratory

Operated for the U.S. Deparment of Energy by Battelle Memorial Institute

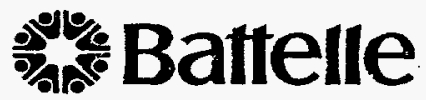




\title{
DISCLAIMER
}

This report was prepared as an account of work sponsored by an agency of the United States Government. Neither the United States Government nor any agency thereof, nor Battelie Memorial Institute, nor any of their employees, makes any warranty, express or implied, or assumes any legal liability or responsibility for the accuracy, completeness, or usefulness of any information, apparatus, product, or process disclosed, or represents that its use would not infringe privately owned rights. Reference herein to any specific commercial product, process, or service by trade name, trademark, manufacturer, or otherwise does not necessarily constitute or imply its endorsement, recommendation, or favoring by the United States Government or any agency thereof, or Battelle Memorial Institute. The views and opinions of authors expressed herein do not necessarily state or reflect those of the United States Government or any agency thereof.

\author{
PACIFIC NORTHWEST NATIONAL LABORATORY \\ operated by \\ BATTELLE \\ for the \\ UNITED STATES DEPARTMENT OF ENERGY \\ under Contract DE-AC06-76RLO 1830
}




\section{DISCLAMIXR}

Portions of this docament may be Illegible in electronic image products. Images are produced from the best available original documenter 


\section{Hanford Site Cleanup and Transition:}

Risk Data Needs for Decision Making

(Hanford Risk Data Gap Analysis Decision Guide)
S. Gajewski
C. Glantz
B. Harper
G. Bilyard
P. Miller

October 1995

Prepared for the U.S. Department of Energy under Contract DE-AC06-76RLO 1830

Pacific Northwest Laboratory

Richland, Washington 99352 


\section{Executive Summary}

Given the broad array of environmental problems, technical alternatives, and outcomes desired by different stakeholders at Hanford, DOE will have to make difficult resource allocations over the next few decades. Although some of these allocations will be driven purely by legal requirements, almost all of the major objectives of the cleanup and economic transition missions involve choices among alternative pathways.

Many of these alternatives differ in the amount of risk they pose to public health, worker health and safety, the environment, and various social, cultural, and economic interests. To make good resourceallocation decisions, each of the major Site problems must be examined for risks in itself and then compared with the risks posed by other Site problems. Moreover, alternative solutions to specific Site problems (e.g., various methods of cleaning up mixed-waste tanks) must be studied to determine the types and magnitude of risks they involve. It is also necessary(1) to understand the aggregate risk of all activities undertaken at the Site in order to demonstrate observance with aggregate exposure requirements at the Site boundary,(2) to assure that cumulative effects of all Site activities are understood, and(3) to show what overall risk reductions, and other benefits, are being purchased with the taxpayers' money.

This study examined the following questions: What risk information is needed to make good decisions at Hanford? How do those data needs compare to the set(s) of risk data that will be generated by regulatory compliance activities and various non-compliance studies that are also concerned with risk?

This analysis examined the Hanford Site missions, the Hanford Strategic Plan, known stakeholder values, and the most important decisions that have to be made at Hanford to determine a minimum domain of risk information required to make good decisions that will withstand legal, political, and technical scrutiny. The primary risk categories include 1) public health, 2) occupational health and safety, 3) ecological integrity, 4) cultural-religious welfare, and 5) socio-economic welfare.

Risk information is needed in each of the above categories in order to compare, contrast, and aggregate risks associated with problem solutions. Various regulatory compliance activities will yield risk data in some of these categories. The risk data that have been or will be generated via compliance with the major environmental laws, such as the Comprehensive Environmental Response and Liability Compensation Act (Superfund) and the National Environmental Policy Act, were characterized at a high level and mapped onto the minimum domain of risk information needs.

This analysis, though necessarily limited, determined that significant risk categories of concern are not currently addressed, and will not be addressed, by compliance activities or other risk studies chartered at the Site. In addition, existing and planned risk data are being produced by different methodologies and expressed in different metrics. Finally, much of the compliance risk data will be produced over a long period of time (such as that from Superfund operable unit risk assessments) and will not be available in time to support fundamental decisions that need to be made now and in the near future. 
There is no regulatory mechanism to assure uniform methodologies and data metrics, to provide an organizing template for assessments of different physical media or geographical locations, or to assure geographical and subject matter reciprocity and "best fit." Indeed, different regulations actually require different types of risk data, thus confounding any holistic risk analysis.

This study concluded that Hanford decision makers need an integrated site-wide picture of risk that includes prospective programmatic and site-wide risk estimates. Ongoing aggregate and comparative risk will need to be evaluated in order to evaluate interim and residual risks. Existing and forthcoming regulatory compliance risk data will need to be supplemented, reconciled, and integrated in order to assure that Site decisions are informed and defensible. This risk information is essential, even if some decisions are driven by non-risk considerations, in order to demonstrate diligence, good management, technical integrity, concern for the values of stakeholders, and accountability to the taxpayers. Finally, highest and best use of existing and future risk data at Hanford can be achieved only with a higher-level integrating function coordinating and guiding the gathering and synthesis of such risk data. 


\section{Acronyms}

\begin{tabular}{|c|c|}
\hline AEA & Atomic Energy Act \\
\hline ALARA & As Low As Reasonably Achievable \\
\hline $\mathrm{CA}$ & corrective action \\
\hline CERCLA & Comprehensive Environmental Response, Compensation, and Liability Act \\
\hline DOE & U.S. Department of Energy \\
\hline $\begin{array}{l}\text { DOE-RL } \\
\text { DQOs }\end{array}$ & $\begin{array}{l}\text { U.S. Department of Energy, Richland Operations Office } \\
\text { data quality objectives }\end{array}$ \\
\hline EIS & environmental impact statement \\
\hline HEDR & Hanford Environmental Dose Reconstruction Project \\
\hline IAP & interested and affected parties \\
\hline ICRP & International Commission on Radiological Protection \\
\hline MCL & maximum contaminant levels \\
\hline MEI & maximally exposed individual \\
\hline NEPA & National Environmental Policy Act \\
\hline NRC & U.S. Nuclear Regulatory Commission \\
\hline OSHA & Occupational Safety and Health Act \\
\hline PFP & Plutonium Finishing Plant \\
\hline RAGs & Risk Assessment Guidance \\
\hline RBDM & risk-based decision making \\
\hline RCRA & Resource Conservation and Recovery Act \\
\hline$S \& T$ & Science and Technology \\
\hline SARs & Safety Analysis Reports \\
\hline SARA & Superfund Amendments and Reauthorization Act \\
\hline SDWA & Safe Drinking Water Act \\
\hline TPA & Tri-Party Agreement \\
\hline
\end{tabular}




\section{Contents}

Executive Summary $\ldots \ldots \ldots \ldots \ldots \ldots \ldots \ldots \ldots \ldots \ldots \ldots$ iii

Acronyms $\ldots \ldots \ldots \ldots \ldots \ldots \ldots \ldots \ldots \ldots \ldots \ldots \ldots \ldots \ldots \ldots \ldots \ldots$

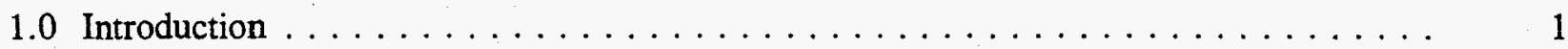

Background $\ldots \ldots \ldots \ldots \ldots \ldots \ldots \ldots \ldots \ldots \ldots \ldots \ldots \ldots \ldots \ldots \ldots \ldots$

Purpose of This Report $\ldots \ldots \ldots \ldots \ldots \ldots \ldots \ldots \ldots \ldots \ldots$

Organization of Report $\ldots \ldots \ldots \ldots \ldots \ldots \ldots \ldots \ldots \ldots \ldots \ldots \ldots$

2.0 Why Risk Information is Needed for Decision Making at Hanford $\ldots \ldots \ldots \ldots$

The Hanford Mission $\ldots \ldots \ldots \ldots \ldots \ldots \ldots \ldots \ldots \ldots$

Hanford Strategic Plan $\ldots \ldots \ldots \ldots \ldots \ldots \ldots \ldots \ldots \ldots$

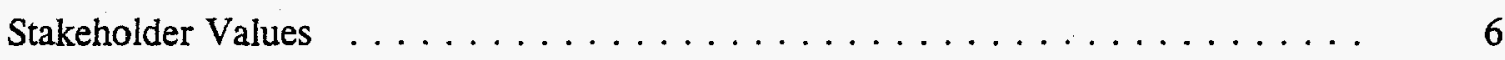

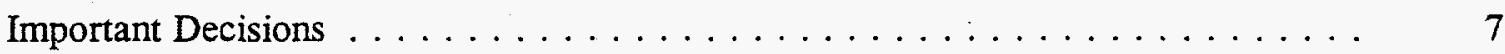

3.0 The Kinds of Risk Information Needed for RBDM at Hanford . . . . . . . . . . . 9

What is the Minimum Domain of Risk Information Needs? . . . . . . . . . . . . 10

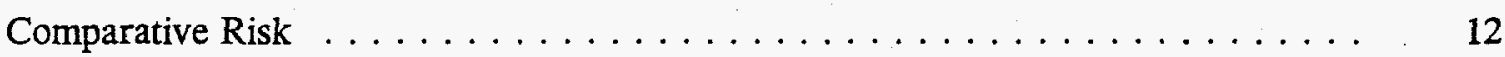

Aggregate Risk ........................ 12

4.0 The Sources of Risk Information at Hanford: Regulatory Compliance

and Other Activities . . . . . . . . . . . . . . . . . . . . . . .

5.0 Gap Analysis: How Do Risk Information Needs Compare to the Risk Information That Is, or Will Become, Available? . . . . . . . . . . . . . . . . . . . . . . . . 19

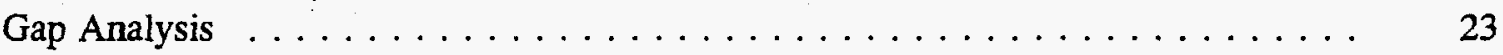

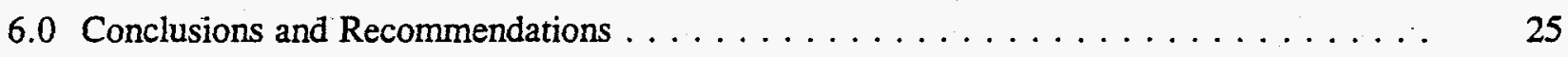

Hanford Site Risk Information Needs . . . . . . . . . . . . . 25 
Appendix A - Hanford Strategic Plan Goals - Hanford Strategic Plan Supplement

October 1994 . . . . . . . . . . . . . . . . . . . . . . . . . . . . . . .

Appendix B - Minimum Domain of Hanford Risk Information Needs Primary Risk

Categories and Salient Parameters . . . . . . . . . . . . . . .

B. 1

Appendix C - Major Regulatory Compliance and Other Programmatic Risk Information

Sources

C.1

Appendix D - Risk Gap Matrix - Laws and Programs

D.1 


\section{Figures}

1 Hanford Site Drivers Mapped to Major Risk Categories . . . . . . . . . . . . . 9

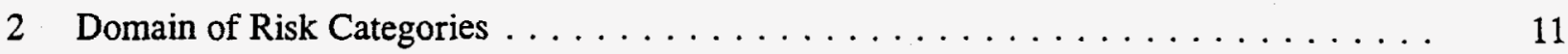

3 Topographical Map of the Primary Risk Categories and Salient Parameters . . . . . . 11

4 Comparative Risk Across Risk Categories and Parameters . . . . . . . . . . 13

5 Comparative Risk of Alternative Solutions Over Time $\ldots \ldots \ldots \ldots \ldots$

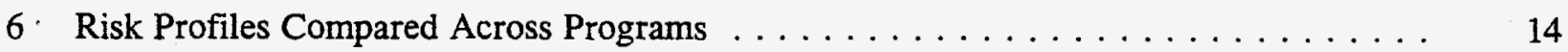

$7 \quad$ Aggregate Site-wide Risk $\ldots \ldots \ldots \ldots \ldots \ldots \ldots \ldots \ldots \ldots \ldots$

8 Atomic Energy Act Risk Requirements Mapped onto Risk Domain . . . . . . . . . . . 19

9 OSHA Risk Requirements Mapped onto Risk Domain . . . . . . . . . . . . . 20

10 RCRA Risk Requirements Mapped onto Risk Domain $\ldots \ldots \ldots \ldots \ldots$

11 CERCLA Risk Requirements Mapped onto Risk Domain . . . . . . . . . . 21

12 NEPA Potential Risk Analyses Mapped onto Risk Domain . . . . . . . . . . . 21

13 HEDR Risk Results Mapped onto Risk Domain $\ldots \ldots \ldots \ldots \ldots \ldots$

14 Representative SARs Risk Data Mapped onto Risk Domain . . . . . . . . . . . . . 22

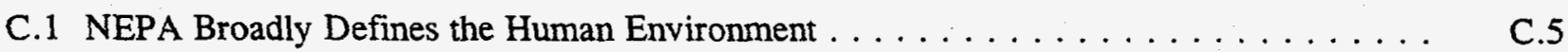




\section{Tables}

1 Summary Analysis of Hanford Strategic Plan Goals $\ldots \ldots \ldots \ldots \ldots$

2 Where is the Dangerous Material at Hanford? $\ldots \ldots \ldots \ldots$

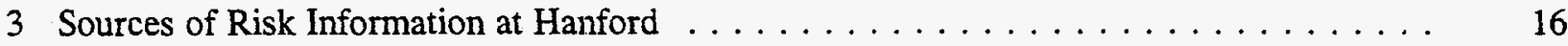




\subsection{Introduction}

\section{Background}

The Hanford Site cleanup mission involves the management of large, complex environmental problems over a period of decades. Each of the many activities now underway and to be undertaken in the future is directed at the protection of public health, worker health, and the environment. Huge volumes of dangerous materials will have to be recovered, moved, treated, and disposed of. Significant areas of high-value native habitat and of cultural importance may have to be disturbed or destroyed. The decisions made about what, how, and how much to clean up Hanford have profound cultural, religious, and socioeconomic implications for the regional stakeholders and for all American taxpayers.

Decision makers will have to choose among alternative technologies with different costs, time requirements, and degrees of effectiveness. Many operations will proceed in parallel, and difficult resource allocations will have to be made to meet cleanup goals and legal obligations with available funding. Many forms of risks posed by many complex activities will have to be considered for each Comprehensive Environmental Response, Compensation and Liability Act (CERCLA) operable unit, Resource Conservation and Recovery Act (RCRA) facility, and nuclear material management facility, both individually and in the aggregate. Individual unit and site-wide aggregate risks will have to be considered for each cleanup alternative and for each possible endstate in order to support determinations about future Site uses.

The U.S. Department of Energy (DOE) and the other stakeholders at Hanford want to spend public money in a way that

- minimizes the dangers to public and worker health

- addresses the most urgent risks first

- reflects cultural and socio-economic values

- protects the environment

- optimizes the balance among all of these goals and the costs of risk reduction.

All stakeholders want to make decisions that are based upon the best possible understanding of the hazards to be abated, the different risks associated with alternative solutions, and the various tradeoffs that will have to be made among different kinds of dangers.

A risk-based decision making (RBDM) process fully comprehends the legitimacy, indeed the necessity, of making some decisions that are not justified by reduction in risks, or which may divert 
resources away from abatement of certain risks. Numerous environmental laws apply to Site activities, and the Tri-Party Agreement contains goals and objectives that are driven by regulatory, political, and cost considerations. However, in a risk-based decision making process, RBDM emphasizes "informed decisions, " that is, decisions made with a basic understanding of the risks, and in a way that an acceptance or rejection of risks will withstand legal, political, and scientific scrutiny.

\section{Purpose of This Report}

What risk information is needed to support an RBDM process at Hanford? What kinds of risk information already exist, or will be produced by the many programs involved in waste management and cleanup at Hanford? How can DOE and stakeholders make the highest and best use of this information to support credible decision making?

This report will identify gaps between risk information being produced (primarily through regulatory compliance activities) and the set of risk information that is needed to make good planning decisions. This report will also examine what kind of effort is required to fill those gaps and to interpret and organize that risk information in a way that is most useful for successfully cleaning up Hanford.

\section{Organization of Report}

This report is organized into the following discussion sections:

- Why Risk Information Is Needed for Decision Making at Hanford

- The Kinds of Risk Information Needed for RBDM at Hanford

- The Sources of Risk Information at Hanford: Regulatory Compliance and Other Activities

- Gap Analysis: How Do Risk Information Needs Compare to the Risk Information That Is, or Will Become, Available?

- Conclusions and Recommendations 


\subsection{Why Risk Information Is Needed for Decision Making at Hanford}

Stakeholders have called for Hanford Management to spend public resources wisely to assure aggressive, efficient actions to reduce hazards and to protect human health and the environment. The public has made it clear that they want DOE to address the matters that the public thinks are important, not just those that DOE and Site operators think are important. DOE has resolved to accomplish these ends in a way that integrates and balances scientific rigor, technical excellence, cost, the values and perceptions of the stakeholders, and the need to act despite uncertainty. The following sections discuss drivers that create the need for integrated risk information at Hanford. These drivers include

- DOE's Missions at Hanford

- The Hanford Strategic Plan

- Stakeholder values

- Important Site cleanup and resource allocation decisions.

These drivers are intertwined with federal, state, and local environmental laws and the Tri-Party Agreement.

\section{The Hanford Mission}

The Hanford Mission has three focus areas:

- Clean up the Site

- Provide scientific and technological excellence to meet global needs

- Partner in the economic diversification of the region.

The determination of cleanup levels for all contaminated parts of the Site, the ultimate disposition of radioactive/hazardous waste and material, and the choices among technologies and future land and resource uses all require determination of current, interim, and endstate risks, and choices among alternative actions and endstates. 


\section{Hanford Strategic Plan}

The DOE-RL's Strategic Plan (and draft Supplement, October 1994) sets forth nine cardinal goals for the Hanford Site. Each of these goals supports the others. Several of these goals explicitly or implicitly require comprehensive risk information for achievement.

- Goal 1: Manage and Reduce Hazards

- Goal 2: Enhance Worker Safety and Health

- Goal 4: Manage Cleanup as a Project

- Goal 6: Improve Decision Making Process

- Goal 7: Science and Technology

- Goal 8: Build Partnerships

Please see Table 1 for a brief analysis of the risk information requirement associated with each of the strategic goals.

Table 1. Summary Analysis of Hanford Strategic Plan Goals

Goal 1: Manage and Reduce Hazards

Goal: 1.0 We will reduce the known hazards in our system while improving the quality of our hazard assessments to guide future decisions on risk mitigation.

Goal \#1 calls, among other things, for a comprehensive river protection strategy and the "use ... of risk assessment information to provide a clear, comprehensive, defensible, and consistent basis for identifying and understanding the real hazards in our system."

Issues: What kind and level of risk analysis is necessary to make good decisions?

What risks and impacts are of greatest concern to stakeholders?

How will risk information from di:ferent programs be made consistent?

What framework will be used to assure that the basis for decision-making is "comprehensive," i.e., that decisions are made with a clear understanding of all of the important hazards on the site over the entire period of the cleanup? 
Goal 2: Enhance Worker Safety and Health

Goal: 2.0 We will enhance the safety and health of Hanford workers.

Evaluation of cleanup aiternatives will require making informed tradeoffs among worker health, public health, and other costs and benefits.

Issues: How will it be determined that increased risk to workers associated with cleanup and waste management activities are warranted by reductions of risk to and impacts on public health, the environment, cultural values, and economic interests?

How will the ALARA concept for radiological and chemical hazards be affected by risk reduction goals in other categories?

\section{Goal 4: Manage Cleanup as a Project}

Goal: 4.0 We will manage the Hanford cleanup as a project by consistently applying project management principles to reach the desired endstate as quickly and cost effectively as possible while considering risks and benefits to the public, the workers, and the environment.

Management of the Hanford cleanup as a project depends upon the ability to compare and aggregate risks across alternative problems solutions within projects and programs, across projects and programs, and across time from beginning to end.

Issues: What mechanism will provide for the presentation of risks across the Site in comparable metrics, or at least in a form that permits stakeholders and decision makers to compare them intuitively or via their own methodology?

What mechanism will integrate risks from different categories of risk and aggregate them to show aggregate site risk?

What mechanism will provide estimates of future risks for purposes of making major decisions that have major long-term implications?

\section{Goal 6: Improve Decision Making Process}

Goal: 6.0 We will have effective decision making across the Hanford Site that balances decision quality, acceptance of the decision by the public, and timeliness of the decision.

Effective decisions that will stand up over time, require an explicit consideration of stakeholder goals and values (including concerns over risks that might be dismissed by conventional quantitative risk assessment), and define a clear, documented basis that comprehensively reflects the tradeoffs among risks and impacts.

Issues: How will hazards across the Site be characterized in a way that comprehends the scientific data and yet integrates the concerns and values of the stakeholders?

What kind of risk characterization processes will enhance the credibility of risk estimates used to make major decisions and to improve the likelihood that those decisions will hold up over time? 
Table 1. (contd)

Goal 7: Science and Technology

Goal: 7.0 We will be leaders in providing science and technology that enhances Hanford cleanup, improves U.S. competitiveness, and supports the regional, national, and international need to balance economic growth responsibility.

Deployment of new technologies at Hanford depends on clearly demonstrating that innovative technologies will reduce hazards quickly and inexpensively enough to defer action on particular problems, or to bypass conventional technologies in favor of new approaches.

Issues: How will stakeholders be persuaded to defer action on a particular problem, such as groundwater cleanup, pending the development of a new technology, such as bioremediation, unless it can be shown that the risk of such a deferment is acceptable?

How can we demonstrate that project life cycle risks are acceptable?

\section{Goal 8: Build Partnerships}

Goal: 8.0 We will establish positive working relationships that will build confidence and enhance trust in Hanford.

Positive relationships with stakeholders ("interested and affected parties" [IAP]) are essential to making decisions that reflect their values and concerns and which will hold up over time.

Issues: How will it be demonstrated to stakeholders that their views of risk are reflected in the decision-making process?

How can risk information be presented to stakeholders in a way that builds trust and confidence that scientific risk analyses deserve strong consideration in making decisions?

How can DOE take credit for risk reductions or demonstrate that decisions based on non-risk considerations were "fully informed" unless clear, comprehensive risk estimates for various problems and alternative solutions are presented early in the decision making process?

For additional details regarding the Hanford Strategic Plan Supplement, please see Appendix A.

\section{Stakeholder Values}

Stakeholder values regarding the management and cleanup of the Site have emerged from such processes as the Future Site Uses Working Group, the Hanford Tank Waste Task Force, and the TriParty Agreement negotiations. The power of stakeholders to nullify major programmatic decisions despite large investments and commitments is evidenced by the 1993 decision to stop using grout as the final waste form for low-activity tank waiste. The Hanford Mission Plan (FY 1995 Draft, Site Guidance) states that

A prerequisite for successful completion of the cleanup mission is obtaining public trust. This trust is essential to gaining the broad public acceptance needed to accomplish Site cleanup. 
Public trust and broad acceptance of Site cleanup decisions cannot be obtained without a decisionmaking process that explicitly integrates stakeholder's values in a manner that is open, understandable, fair, and effective enough to survive downstream challenges and the budget cycle.

Major stakeholder values include

- Protecting the environment

- Taking early steps to protect the Columbia River

- Protecting public/worker health and safety

- Getting on with the cleanup

- Using a systems-design approach that keeps endpoints in mind as intermediate decisions are made

- Establishing management practices that ensure accountability, efficiency, and allocation of funds to high-priority items.

These stakeholder values determine which hazards the stakeholders want their government to address, the urgency with which they want them addressed, and the acceptability of technology choices and problem solutions. A clear picture of the "hazards" or risks at the Hanford Site is essential to support a process of discussion, education, and negotiation about realistic priorities and the best use of limited resources. Key decisions that will have to be made within this RBDM framework are shown below.

\section{Important Decisions}

Many important site decisions cannot be made without a broad, integrated picture of risk. Such decisions include

- What are endstate land uses for particular areas of the Site?

- Should the central plateau be a "national sacrifice" zone?

- Should large groundwater plumes be treated?

- Should unspoiled old-growth or mature shrub-steppe habitat be disturbed for solid waste burial?

- What are appropriate cleanup standards for CERCLA remediation units and RCRA facilities?

- Should Special Nuclear Materials be processed onsite before shipment offsite? 
- What technologies should be used for characterization, retrieval, separation, and final treatment of tank waste?

- What is the best disposal form for low-level radioactive waste?

It is not within DOE's, the state's, nor the nation's power to deliver perfect solutions to each of the problems at Hanford. This nation cannot afford the absolute restoration of the Hanford Site to its native condition, nor do all (or even most) stakeholders agree that such a restoration is desirable. Every one of these major decisions will therefore require clear, understandable tradeoffs among clear, credible alternatives, and finally, clear, defensible allocations of resources.

Without a comprehensive depiction of the hazards at Hanford, DOE and its contractors will be unable to report what risk reductions were achieved, and at what cost, to Congress, to Hanford stakeholders, and to the greater public. The association between risk and contaminant "source terms" or hazardous materials inventories is simply not intuitive. As Table 2 dramatically illustrates, a hazard ranking based on volumes of contaminated media would look very different from a hazard ranking based on radioactive/hazardous material mass. To further complicate matters, neither ranking would show relative risks across major risk categories; nor would it reflect the comparative risks associated with different management, cleanup, and disposal alternatives.

Table 2. Where Is the Dangerous Material at Hanford?

\begin{tabular}{|l|c|c|c|c|}
\hline & $\begin{array}{c}\text { Soil/ } \\
\text { Groundwater }\end{array}$ & Tanks & $\begin{array}{c}\text { Special Nuclear } \\
\text { Material (inc. SNF/Pu) }\end{array}$ & $\begin{array}{c}\text { Solid } \\
\text { Waste }\end{array}$ \\
\hline Volume & $99 \%$ & $<1 \%$ & $<1 \%$ & $<1 \%$ \\
\hline Radionuclide Mass & & $55 \%$ & $45 \%$ & $15 \%$ \\
\hline $\begin{array}{l}\text { Hazardous Waste Mass } \\
\text { (Metals/Organics) }\end{array}$ & $25 \%$ & $60 \%$ & & \\
\hline Source: Jim Honeyman, Al Pajunen, and Roy Gephart, personal communications. \\
\hline
\end{tabular}




\subsection{The Kinds of Risk Information Needed for RBDM at Hanford}

The Hanford Site missions, strategies, and values can be mapped to specific categories of risk that must be addressed for major decisions (see Figure 1). These categories of risk can be used to define a simplified domain of risk information necessary for RBDM at Hanford.

\begin{tabular}{|l|}
\hline Primary Risk Categories \\
\hline - Public Health Risk \\
- Occupational Health Risk \\
- Ecological Risk \\
- Cultural-Religious Risk \\
- Socio-Economic Risk \\
\hline
\end{tabular}

The characterization of risk in each of these primary categories is a complex problem. Risk can be expressed in many different ways, from mortality in the health risk categories to reductions of access to sacred foods in the cultural-religious categories.

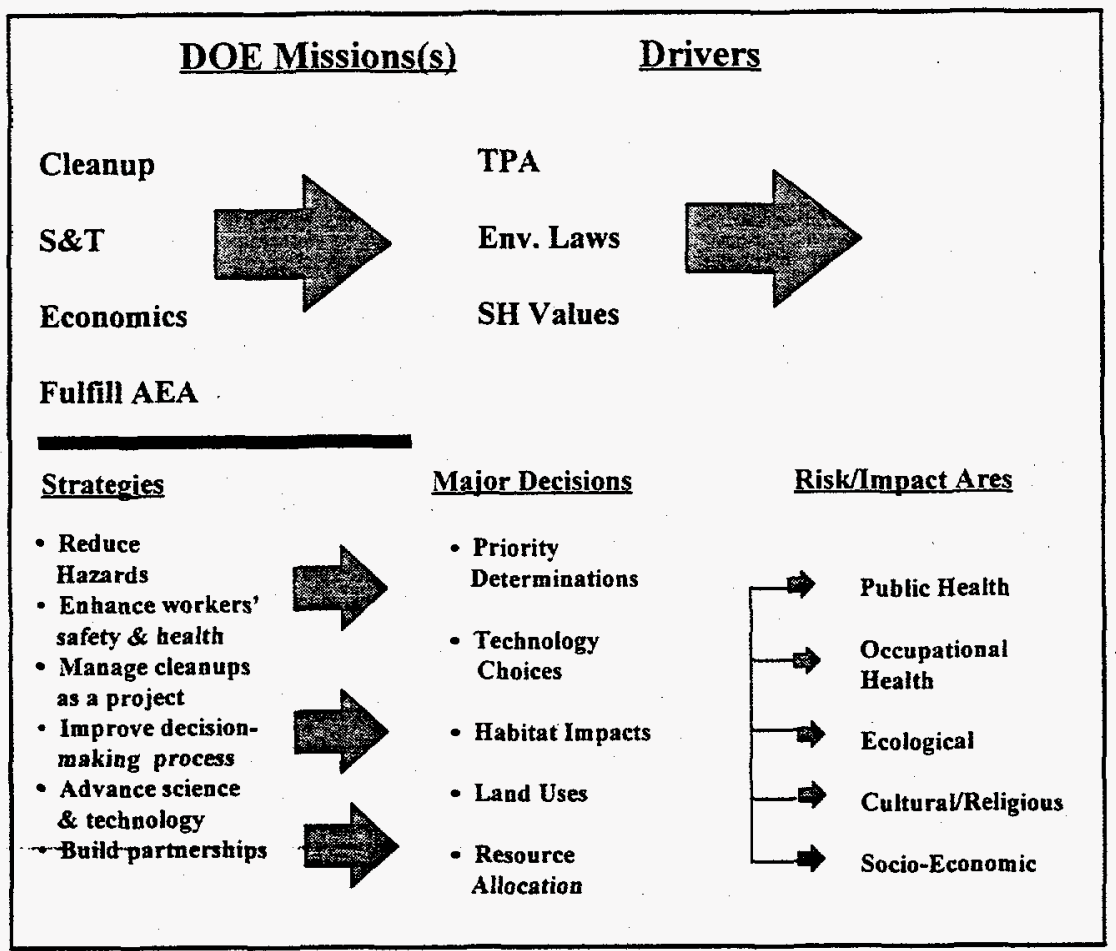

Figure 1. Hanford Site Drivers Mapped to Major Risk Categories. 
Human health risk assessment is a fairly mature science, and conventional measures of public and occupational health risks are widely recognized and used. However, ecological risk, which involves complex issues of diversity, balance and interdependence, is an emerging area of study, and culturalreligious and socio-economic risks pose significant challenges to effective and understandable characterizations.

Even if well-developed measures of all of these risk parameters were available, there would remain the dilemma of comparing different types of risk with one another. How, for example, does one compare cancer hazard to reductions in biodiversity? In all of the categories, risk characterization is inextricably intertwined with values, assumptions, and perceptions that are difficult to identify, express, and measure; these "soft" variables are crucial aspects of risk characterization in any category.

To honor the values of Hanford stakeholders and spend public money wisely, different categories of risks must be compared in a consistent and defensible way among alternative solutions to specific problems, and also among different programs which together make up the complex Hanford "project."

\section{What is the Minimum Domain of Risk Information Needs?}

What kinds of risk information need to be gathered to characterize the risks in the major categories? A rigorous parametric design for broad-spectrum risk assessments involves numerous variables within each category, all of which may themselves have different geographic and/or temporal ranges and/or modes of expression (metrics). However, a simplified set of parameters can be described for each risk category based on

- Existing literature and risk-assessment methodologies

- Values expressed by Hanford stakeholders

- The kinds of decisions that need to made at Hanford.

A representative minimum set of parameters designed to reflect the Hanford domain of risk information needs is shown in the box (Figure 2) and represented graphically in Figure 3. For a more detailed presentation of these parameters, please see Appendix B.

Determination of the simplified risk domain for any particular action would provide decision makers with the information they need on human health, environmental, cultural, and economic impacts to make intelligent decisions about Site management and cleanup.

Determination of a standard basis (clomain) of risk information for major actions would provide decision makers with improved capabilities for weighing human health, environmental, cultural and economic impacts in their decision-making process. 


Public Health Risk
MEl Cancers
Excess Cancers Affected Population
Excess Non-Cancer Hazard
Excess Chronic Toxiological Effects
Occupational Health Risk
Lost Time/Absenteeism
Violation of Exposure/Dose Limits
Injuries and Off-Normal Events
Worker Fatalities
IIlness Rates
Ecological Risk
Reduction of Species Diversity and Abundance
Habitat Degradation and Destruction
Reduction of Ecosystem Function
Cultural-Religious Risk
Size of Cultural/Religious Areas Degraded
Number of Cultural/Religious Sites Degraded
Cultural/Religious Resource Availability
Socio-Economic Risk
Community Infrastructure Impacts
Industrial Commercial Impacts
Agricultural Impacts
Recreational Impacts

Figure 2. Domain of Risk Categories

\begin{tabular}{|c|c|c|c|c|}
\hline \multicolumn{5}{|c|}{ Risk Domain } \\
\hline $\begin{array}{c}\text { Excess } \\
\text { Hazard to } \\
\text { Affected } \\
\text { Population }\end{array}$ & $\begin{array}{c}\text { Exceed } \\
\text { Exposure } \\
\text { and } \\
\text { Dose Limits }\end{array}$ & $\begin{array}{c}\text { Diminished } \\
\text { Species } \\
\text { Abundance } \\
\text { and } \\
\text { Diversity }\end{array}$ & $\begin{array}{c}\text { Religious/ } \\
\text { Cultural (RC) } \\
\text { Area } \\
\text { Degraded }\end{array}$ & $\begin{array}{c}\text { Industrial } \\
\text { Commercial }\end{array}$ \\
\hline $\begin{array}{c}\text { Excess } \\
\text { Cancers in } \\
\text { Affected } \\
\text { Population }\end{array}$ & $\begin{array}{c}\text { Injuries } \\
\text { and } \\
\text { Off-Normal } \\
\text { Events }\end{array}$ & $\begin{array}{c}\text { Habitat } \\
\text { Destruction } \\
\text { or } \\
\text { Degradation }\end{array}$ & $\begin{array}{c}\text { R/C Sites } \\
\text { Disturbed }\end{array}$ & Agricultural \\
\hline $\begin{array}{c}\text { MEl } \\
\text { Cancers }\end{array}$ & $\begin{array}{c}\text { Worker } \\
\text { Fatalities }\end{array}$ & $\begin{array}{c}\text { Reduction } \\
\text { in } \\
\text { Ecosystem } \\
\text { Function }\end{array}$ & $\begin{array}{c}\text { Resource } \\
\text { Availability }\end{array}$ & Recreational \\
\hline $\begin{array}{c}\text { Public } \\
\text { Health } \\
\text { Risk }\end{array}$ & $\begin{array}{c}\text { Occup. } \\
\text { Health } \\
\text { Risk }\end{array}$ & $\begin{array}{c}\text { Ecological } \\
\text { Risk }\end{array}$ & $\begin{array}{c}\text { Cultural/ } \\
\text { Religious } \\
\text { Risk }\end{array}$ & $\begin{array}{c}\text { Economic } \\
\text { Risk }\end{array}$ \\
\hline
\end{tabular}

Figure 3. Topographical Map of the Primary Risk Categories and Salient Parameters 
To present such risk information, however, is to demand comparisons. Every significant action at Hanford is going to involve a tradeoff among different risks. Just as importantly, every significant action at Hanford is going to contribute to the aggregate risks for the Site as a whole. Decision-making at Hanford, therefore, depends upon comparison and aggregation of risk across risk subcategories and across projects and programs. Furthermore, comparison and aggregation must be done predictively in order to characterize interim and endstate risks and periodically in order to measure actual interim and endstate risks.

\section{Comparative Risk}

Given a minimum domain of risk information, the following risk comparisons have to be made in order to support intelligent decisions at Hanford:

- For each proposed course of action ("solution") the risks in the various categories and subcategories need to be compared with one another (see Figure 4).

- Alternative solutions to a single problem have to be compared to one another, and that comparison must reflect the changes in risk over time from start to finish (see Figure 5).

- Categorical and aggregate risks have to be compared across major projects or programs to support difficult priority and resource-allocation decisions (see Figure 6).

\section{Aggregate Risk}

Determination of the aggregate risk of Hanford activities is necessary to

- Ensure that exposure limits at the Site boundary are met

- Provide the basis for allocation of risk "quotas" to certain designated activities to ensure compliance with Site boundary limits, occupational exposure limits, and DOE guidance

- Support scheduling of activities to minimize aggregate site-wide risk and provide maximum "cushion" around any particular "unavoidable" risk

- Demonstrate site-wide reduction of hazards over the lifetime of the cleanup, and provide a "big picture" to provide perspective on any particular risk-abatement decisions

- Provide context for the determination of "how much and how good" risk information is needed to make intelligent decisions (data quality objectives).

In order to accomplish these objectives, aggregate risks need to be estimated before (in part by reconstruction), during, and after cleanup (see Figure 7). 


\begin{tabular}{|c|c|c|c|c|}
\hline \multicolumn{5}{|c|}{ Comparative Risk } \\
\hline $\begin{array}{c}\text { Excess } \\
\text { Non-Cancer } \\
\text { Hazafolo } \\
\text { Affese } \\
\text { Population }\end{array}$ & $\begin{array}{c}\text { Exceed } \\
\text { Exposure } \\
\text { and } \\
\text { Dose Limits }\end{array}$ & $\begin{array}{c}\text { Species } \\
\text { Abundance } \\
\text { and } \\
\text { Diversity }\end{array}$ & $\begin{array}{l}\text { Religious/ } \\
\text { Cultural } \\
\text { Area } \\
\text { Degraded }\end{array}$ & $\begin{array}{c}\text { Industrial } \\
\text { Commerjial }\end{array}$ \\
\hline $\begin{array}{l}\text { Excess } \\
\text { Cancers in } \\
\text { Affected } \\
\text { Population }\end{array}$ & $\begin{array}{c}\text { Injuries } \\
\text { and } \\
\text { Off-Normal } \\
\text { Events }\end{array}$ & Destructio & $\begin{array}{l}\text { Rle sit } \\
\text { Bicturb }\end{array}$ & Agricultural \\
\hline MEI & & $\begin{array}{c}\begin{array}{c}\text { Reduction } \\
\text { in } \\
\text { Ecosystem } \\
\text { Function }\end{array} \\
\text {. }\end{array}$ & $\begin{array}{l}\text { Restive } \\
\text { Availability }\end{array}$ & Recreational \\
\hline $\begin{array}{l}\text { Public } \\
\text { Health } \\
\text { Risk }\end{array}$ & $\begin{array}{c}\text { Occup. } \\
\text { Health } \\
\text { Risk }\end{array}$ & $\begin{array}{l}\text { Ecological } \\
\text { Risk }\end{array}$ & $\begin{array}{c}\text { Cultural/ } \\
\text { Religious } \\
\text { Risk }\end{array}$ & $\begin{array}{l}\text { Socio- } \\
\text { Economic } \\
\text { Risk }\end{array}$ \\
\hline
\end{tabular}

Figure 4. Comparative Risk Across Risk Categories and Parameters

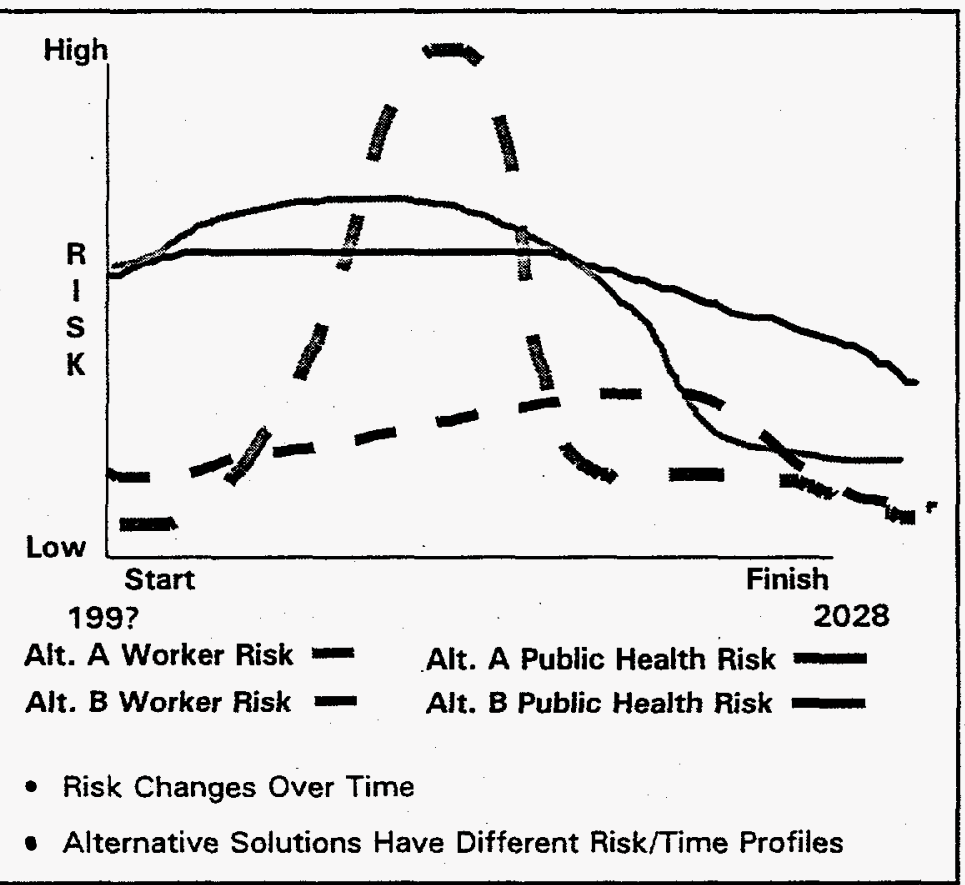

Figure 5. Comparative Risk of Alternative Solutions Over Time 


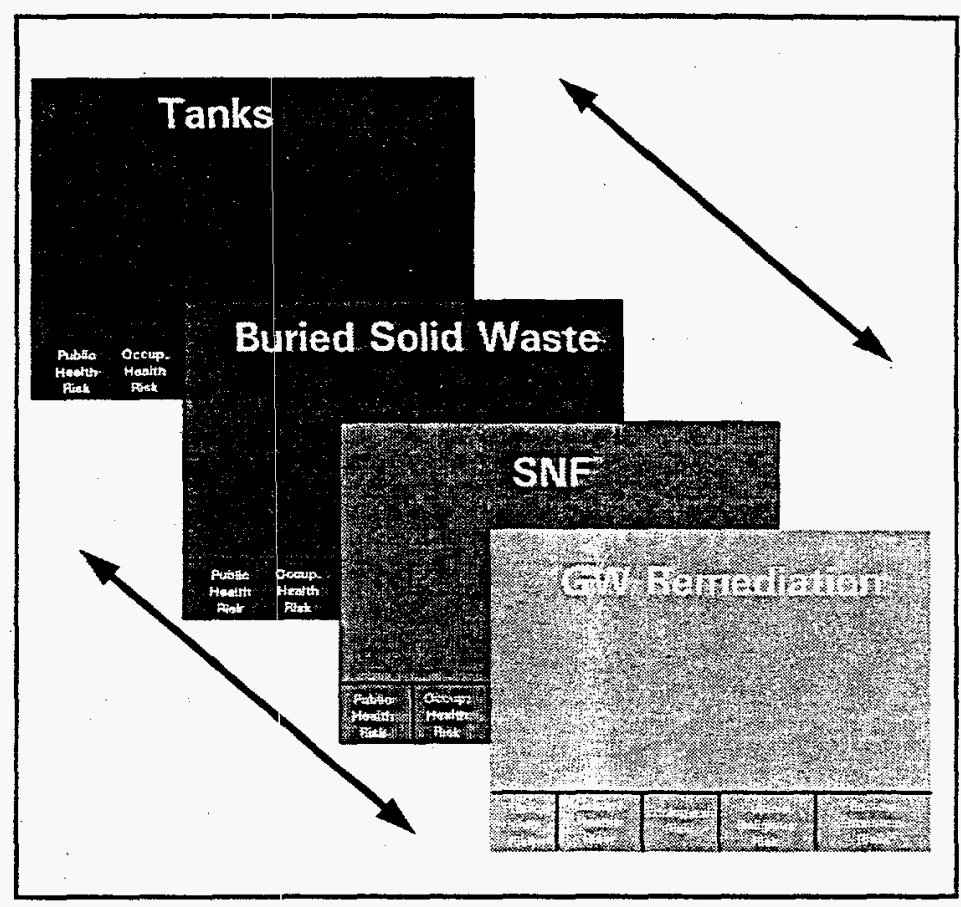

Figure 6. Risk Profiles Compared Across Programs

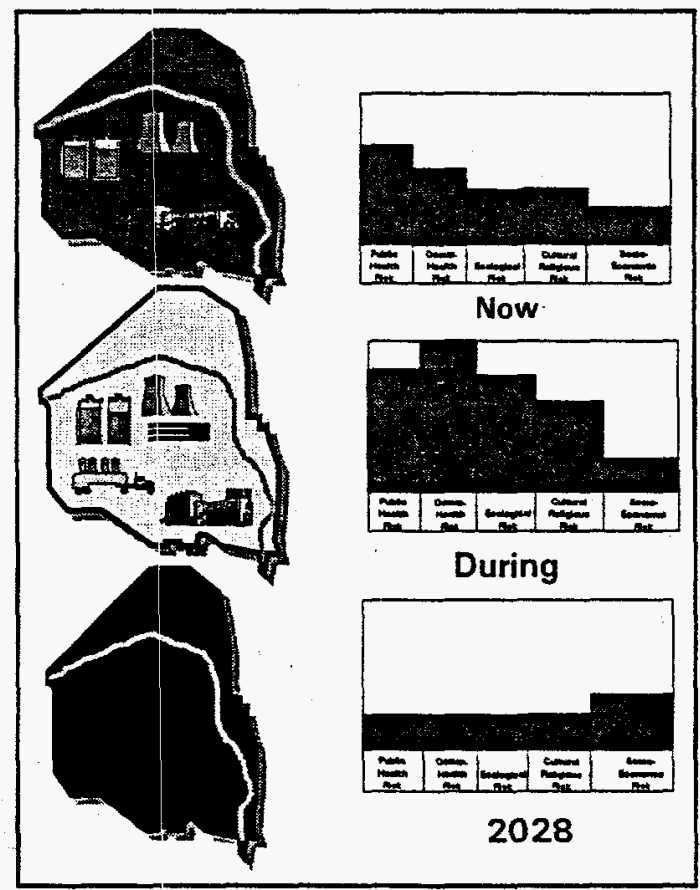

Figure 7. Aggregate Site-wide Risk 


\subsection{The Sources of Risk Information at Hanford: Regulatory Compliance and Other Activities}

What kinds of risk information have been and will be gathered via regulatory compliance and other activities at Hanford, and how does that risk information compare to the domain of risk information needs?

Substantial amounts of risk information are gathered in the course of complying with major environmental laws that govern the Hanford Site operations and cleanup (compliance risk data). In addition, there are other risk-oriented projects and programs that have been, or are being, undertaken to comply with DOE standards or to meet specific programmatic needs, such as the Hanford Environmental Dose Reconstruction Project.

The major regulatory compliance activities that involve or require the generation of significant risk information are conducted under the following major environmental laws:

- Atomic Energy Act

- Occupational Safety and Health Act

- Resource Conservation and Recovery Act

- Comprehensive Environmental Response, Compensation and Liability Act

- National Environmental Policy Act

Programs and activities that involve the production of significant risk information include

- Hanford Environmental Dose Reconstruction Project

- Safety Analysis Reports for various facilities.

A summary of the risk information generated pursuant to each of the major environmental acts and various Hanford programs is shown in the box (see Table 3). For a more detailed summary analysis of risk information sources, please see Appendix C. 
Table 3. Sources of Risk Information at Hanford

\section{Atomic Energy Act (AEA) (42 U.S.C. 2011 et seq.)}

AEA confers upon DOE the general obligation and the authority to protect the health and safety of the public.

\section{Risk Data Required for Compliance}

- The AEA requires no specific risk information, but fulfillment of AEA's requirement to protect the welfare of the public requires comprehensive risk information.

\section{Issues}

- DOE must protect the health and welfare of the public.

- Compliance with regulations is part of DOE's bottom line, and is not a measure of DOE's responsibilities.

\section{Occupational Safety and Health Act (OSHA) (29 U.S.C. 651 et seq.)}

OSHA requires employers to protect the health and safety of employees in the workplace.

\section{Risk Data Required for Compliance}

- OSHA requires hazard prevention and compliance with risk-based exposure limits.

- OSHA does not require any specific risk analysis

\section{Issues}

- OSHA exposure limits are based on criteria specific to the workplace; comparison to and balance against public health risk measures is a challenge.

\section{Resource Conservation and Recovery Act (RCRA), as amended by the Hazardous and Solid Waste Amendments (42 U.S.C. 6901 et seq.)}

RCRA, which governs hazardous waste management, transportation, and disposal, requires worker training and protection, but because of its focus on industrial facilities, it plays a small role in risk analysis.

\section{Risk Data Required for Compliance}

- As a part of its permitting process, RCRA requires assessment of risks to public health and the environment from normal operations and accidents at hazardous waste management facilities. RCRA may also require risk assessments for releases from regulated waste management units.

\section{Issues}

- RCRA's purview of risk is limited to hazardous waste management activities and releases of hazardous constituents from regulated facilities and their solid waste management units. 
Table 3. (contd)

Comprehensive Environmental Response, Compensation, and Liability Act (CERCLA) as amended by the Superfund Amendments and Reauthorization Act (SARA) (42 U.S.C. 9601 et seq.)

CERCLA provides for cleanup of hazardous substances, including radionuclides, that have been released to the environment. Section 121 of CERCLA requires that remedial actions attain a level of cleanup which "at a minimum assures protection of human health and the environment."

\section{Risk Data Required for Compliance}

- CERCLA requires extensive site characterization studies and analysis of risks associated with exposures to hazardous substances.

\section{Issues}

- Methodologies for ecological risk assessment and other non-health risk categories are in developmental stages.

- Site-specific analyses are quite variable in scope and level of detail.

- A CERCLA risk analysis is required for each Operable Unit at Hanford. CERCLA provides no vehicle for assessment of risk across multiple operable units or in relation to Hanford's other regulated activities.

- Operable Unit risk analyses will be produced individually over a long period of time.

\section{National Environmental Policy Act (NEPA) (42 U.S.C. 4321 et seq.)}

NEPA requires analysis and public review of the potential environmental impacts of major federal actions. Impacts of concern can include human health and safety, socioeconomic, ecological, aesthetic, and other impacts. Cumulative impacts must be addressed.

\section{Risk Data Required for Compliance}

- Potential environmental impacts of major federal actions can often be characterized in terms of risk; NEPA analyses and reviews for such actions may require analysis of a variety of forms of risk.

\section{Issues}

- Many NEPA reviews are in progress at Hanford.

- There are no uniform protocols for risk assessment in NEPA reviews.

- Determination of environmental impact statements' (EIS) risk-assessment scope, methodology, and reciprocity is not being done systematically across the Site.

- Reconciliation and aggregation of risk information in NEPA reviews is not required by NEPA or other environmental laws.

- NEPA requires only predictive analysis of alternatives; there is no provision for outcome assessment. 
Table 3. (contd)

\section{Hanford Environmental Dose Reconstruction Project}

This project provided a means for people to estimate their individual radiation doses from past Hanford releases (1944-1988) based on their age, sex, place of residence, and diet.

\section{Risk Data Required for Compliance}

- Not applicable

\section{Issues}

- Extremely limited dose calculations for "downwinders" are not very useful for the risk picture of the Site itself.

\section{Safety Analysis Reports}

SARs assure that safety measures have been applied at specific process points to reduce the probability of release events, so that the combination of probability and dose falls within DOE and related guidelines.

\section{Risk Data Required for Compliance}

- Individual events/sources in operating nuclear facilities are analyzed to determine probability of release that will exceed dose.

\section{Issues}

- SARs provide for no aggregation of events and sources across all of Hanford's nuclear facilities and nuclear materials management activities.

- SAR exposure pathway analyses are limited in scope and are not compatible with other forms of risk assessment.

- Impacts are expressed solely in terms of short-term (acute or annual) dose.

- SARs are almost entirely concerned with radiation. 


\subsection{Gap Analysis: How Do Risk Information Needs Compare to the Risk Information That Is, or Will Become, Available?}

Is the risk information that is, or will be, generated by these activities sufficient to support riskbased decision making at Hanford now and in the future?

The risk information that has been, or will be, generated by these activities (mostly compliance risk data) can be mapped against the representative minimum risk information needs domain. The kind and amount of risk data generated by each of these Hanford activities (risk information sets) has been evaluated in a summary manner against each of the risk parameters that make up the risk information needs domain (see Appendix D for a matrix showing the results of this analysis). The activities under analysis are highly complex and variable; therefore, exceptions and special cases exist in many of the parametric "cells." However, the simplified mapping correctly portrays the general coverage associated with Hanford risk information sets.

Figures 8 through 14 show the coverage for each major compliance activity (such as RCRA or CERCLA) or other program. These figures do not reflect the fact that some data sets will be filled over time, e.g., as environmental impact statements (EISs) are written for various projects or programs, or as CERCLA risk analyses are conducted for individual operable units. This is very important, because in order to make good long-term decisions, good risk estimates need to be made for many programmatic activities long before the Site-specific risk assessments are actually conducted "on the ground" or in an appropriate EIS.

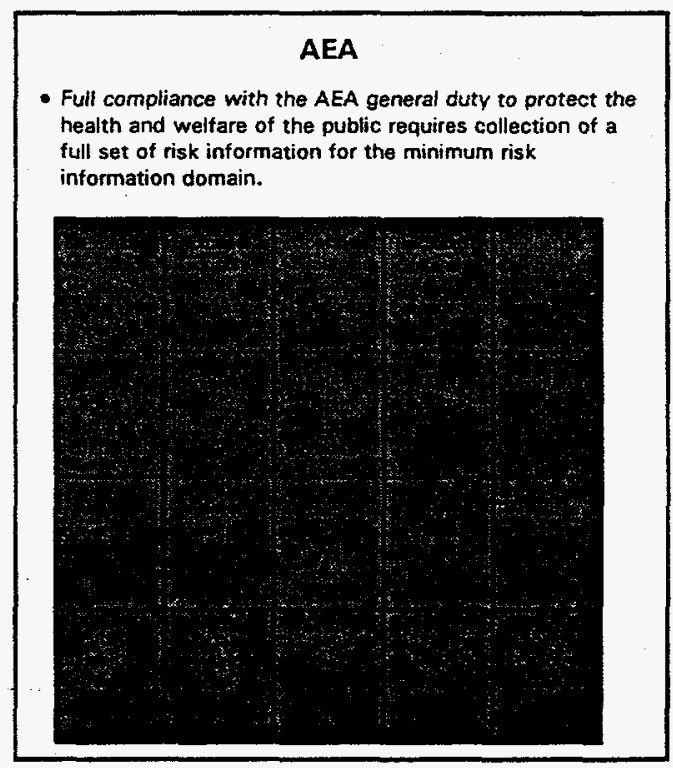

Figure 8. Atomic Energy Act Risk Requirements Mapped onto Risk Domain (Blank = no data; Light $=$ some data; Dark $=$ significant data $)$ 


\begin{tabular}{|c|c|c|c|c|}
\hline \multicolumn{5}{|c|}{$\begin{array}{l}\text { OSHA } \\
\text { - OSHA is prevention and compliance oriented } \\
\text { - No risk analysis required } \\
\text { - Occupatiorial exposure limits not comparable to public } \\
\text { exposure linits }\end{array}$} \\
\hline $\begin{array}{c}\text { Excess } \\
\text { Non-Cancer } \\
\text { Hazard to } \\
\text { Affected } \\
\text { Population }\end{array}$ & $\frac{1}{3}$ & $\begin{array}{l}\text { Species } \\
\text { Abundance } \\
\text { and } \\
\text { Diversity }\end{array}$ & $\begin{array}{l}\text { Religious/ } \\
\text { Cultural } \\
\text { Area } \\
\text { Degraded }\end{array}$ & $\begin{array}{c}\text { Industrial } \\
\text { Commercial }\end{array}$ \\
\hline $\begin{array}{c}\text { Excess } \\
\text { Cancers in } \\
\text { Affected } \\
\text { Population }\end{array}$ & 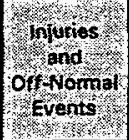 & $\begin{array}{c}\text { Habitat } \\
\text { Destruction } \\
\text { or } \\
\text { Degradation }\end{array}$ & $\begin{array}{l}\text { R/C Sites } \\
\text { Disturbed }\end{array}$ & Agricultural \\
\hline $\begin{array}{c}\text { MEl } \\
\text { Cancers }\end{array}$ & Worker & $\begin{array}{l}\text { Reduction } \\
\text { in } \\
\text { Ecosystem } \\
\text { Function }\end{array}$ & $\begin{array}{c}\text { R/C } \\
\text { Resource } \\
\text { Availability }\end{array}$ & Recreationai \\
\hline $\begin{array}{l}\text { Public } \\
\text { Health } \\
\text { Risk }\end{array}$ & $\begin{array}{c}\text { Occup. } \\
\text { Health } \\
\text { Risk }\end{array}$ & $\begin{array}{l}\text { Ecological } \\
\text { RIsk }\end{array}$ & $\begin{array}{l}\text { Cultural/ } \\
\text { Religious } \\
\text { Risk }\end{array}$ & $\begin{array}{l}\text { Socio- } \\
\text { Economic } \\
\text { Risk }\end{array}$ \\
\hline
\end{tabular}

Figure 9. OSHA Risk Requirements Mapped onto Risk Domain $($ Blank $=$ no data $;$ Light $=$ some data $;$ Dark $=$ significant data $)$

\begin{tabular}{|c|c|c|c|c|}
\hline \multicolumn{5}{|c|}{$\begin{array}{l}\text { RCRA } \\
\text { - RCRA oriented toward industrial facilities } \\
\text { - Corrective action (CA) geared towards groundwater } \\
\text { - CA standards usually background or Safe Drinking Wate } \\
\text { Act (SDWA) Maximum Contaminant Levels (MCL's) }\end{array}$} \\
\hline $\begin{array}{l}\text { Excess } \\
\text { Non Cancer } \\
\text { Hezard to } \\
\text { Alfected } \\
\text { Population }\end{array}$ & $\begin{array}{c}\text { Exceed } \\
\text { Exposure } \\
\text { and } \\
\text { Dose Limits }\end{array}$ & $\begin{array}{l}\text { Species } \\
\text { Abundance } \\
\text { and } \\
\text { Diversity }\end{array}$ & $\begin{array}{l}\text { Religious/ } \\
\text { Cuttural } \\
\text { Area } \\
\text { Degraded }\end{array}$ & 8 \\
\hline \multirow[t]{2}{*}{$\begin{array}{l}\text { Hexess } \\
\text { Cancers lh } \\
\text { Affected } \\
\text { Population }\end{array}$} & & $\begin{array}{c}\text { Habitat } \\
\text { Destruction } \\
\text { or } \\
\text { Degradation }\end{array}$ & $\begin{array}{l}\text { R/C Sites } \\
\text { Disturbed }\end{array}$ & Agricultural \\
\hline & $\begin{array}{l}\text { Worker } \\
\text { Fatalities }\end{array}$ & $\begin{array}{l}\text { Reduction } \\
\text { in } \\
\text { Ecosystem } \\
\text { Function }\end{array}$ & $\begin{array}{c}\text { R/C } \\
\text { Resource } \\
\text { Availability }\end{array}$ & Recreational \\
\hline $\begin{array}{l}\text { Public } \\
\text { Mestth } \\
\text { Risk }\end{array}$ & $\begin{array}{c}\text { Occup. } \\
\text { Health } \\
\text { Risk }\end{array}$ & $\begin{array}{l}\text { Ecological } \\
\text { Risk }\end{array}$ & $\begin{array}{l}\text { Culturall } \\
\text { Religious } \\
\text { Risk }\end{array}$ & $\begin{array}{l}\text { Socio- } \\
\text { Economic } \\
\text { Risk }\end{array}$ \\
\hline
\end{tabular}

Figure 10. RCRA Risk Requirements Mapped onto Risk Domaị $($ Blank $=$ no data $;$ Light $=$ some data $;$ Dark = significant data $)$ 


\section{CERCLA}

- CERCLA requires broad risk analysis and balancing of factors.

- Site-specitic analyses are variable.

- One-unit-at-a-time approach means no programmatic aggregate risk projections.

\begin{tabular}{|c|c|c|c|c|}
\hline $\begin{array}{l}\text { Excess } \\
\text { varchancer } \\
\text { Hezard to } \\
\text { Affected } \\
\text { Poputilion }\end{array}$ & 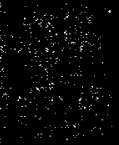 & $\begin{array}{l}\text { Species } \\
\text { Abundance } \\
\text { and } \\
\text { Diversity }\end{array}$ & $\begin{array}{l}\text { Religious/ } \\
\text { Cultural } \\
\text { Area } \\
\text { Degraded }\end{array}$ & $\begin{array}{l}\text { Industrial } \\
\text { Commercial }\end{array}$ \\
\hline $\begin{array}{l}\text { Excess } \\
\text { Cancers in } \\
\text { Affectod } \\
\text { population }\end{array}$ & $\begin{array}{l}\text { injuries } \\
\text { and } \\
\text { Oft-Normal } \\
\text { Events }\end{array}$ & $\begin{array}{c}\text { Habitat } \\
\text { Destruction } \\
\text { or } \\
\text { Degradation }\end{array}$ & $\begin{array}{l}\text { PYC Sites } \\
\text { Disturbed }\end{array}$ & Agricultura \\
\hline & $\begin{array}{l}\text { Worker } \\
\text { Fatalities }\end{array}$ & $\begin{array}{l}\text { Reduction } \\
\text { in } \\
\text { Ecosystem } \\
\text { Function }\end{array}$ & $\begin{array}{c}R / C \\
\text { Resource } \\
\text { Availability }\end{array}$ & Recreational \\
\hline $\begin{array}{l}\text { Public } \\
\text { Health } \\
\text { Risk }\end{array}$ & $\begin{array}{l}\text { Occup. } \\
\text { Heaith } \\
\text { Alsk }\end{array}$ & $\begin{array}{l}\text { Ecological } \\
\text { Risk }\end{array}$ & $\begin{array}{c}\text { Cultural/ } \\
\text { Religious } \\
\text { Risk }\end{array}$ & $\begin{array}{l}\text { Socio- } \\
\text { Economic } \\
\text { Risk }\end{array}$ \\
\hline
\end{tabular}

Figure 11. CERCLA Risk Requirements Mapped onto Risk Domain $($ Blank $=$ no data $;$ Light $=$ some data $;$ Dark $=$ significant data $)$

\section{NEPA}

- Requires broad analysis of impacts

- Could be excellent vehicle for sitewide risk picture

\begin{tabular}{|c|c|c|c|c|}
\hline $\begin{array}{l}\text { Excess } \\
\text { Non Cancer } \\
\text { Hazard to } \\
\text { Affected } \\
\text { Population }\end{array}$ & $\begin{array}{l}\text { Exceed } \\
\text { Exposure } \\
\text { and } \\
\text { Dose Limits }\end{array}$ & $\begin{array}{l}\text { Species } \\
\text { Abundance } \\
\text { and } \\
\text { Diversity }\end{array}$ & $\begin{array}{c}\text { Religious/ } \\
\text { Cultural } \\
\text { Area } \\
\text { Degraded }\end{array}$ & $\begin{array}{l}\text { Industrial } \\
\text { Commercial }\end{array}$ \\
\hline $\begin{array}{l}\text { Excoss } \\
\text { Cancers in } \\
\text { Affocted } \\
\text { Population }\end{array}$ & $\begin{array}{l}\text { Injuries } \\
\text { and } \\
\text { Off-Normal } \\
\text { Events }\end{array}$ & $\begin{array}{c}\text { Habitat } \\
\text { Destruction } \\
\text { or } \\
\text { Degradation }\end{array}$ & $\begin{array}{l}\text { R/C Sites } \\
\text { Disturbed }\end{array}$ & Agricultural \\
\hline & $\begin{array}{l}\text { Worker } \\
\text { Fatalities }\end{array}$ & $\begin{array}{l}\text { Reduction } \\
\text { in } \\
\text { Ecosystem } \\
\text { Function }\end{array}$ & $\begin{array}{c}\text { R/C } \\
\text { Resource } \\
\text { Availability }\end{array}$ & Recreational \\
\hline $\begin{array}{l}\text { Public } \\
\text { Hearth } \\
\text { Risk }\end{array}$ & $\begin{array}{c}\text { Occup. } \\
\text { Heaith } \\
\text { Risk }\end{array}$ & $\begin{array}{c}\text { Ecological } \\
\text { Risk }\end{array}$ & $\begin{array}{c}\text { Cultural/ } \\
\text { Religious } \\
\text { Aisk }\end{array}$ & $\begin{array}{l}\text { Socio- } \\
\text { Economic } \\
\text { Risk }\end{array}$ \\
\hline
\end{tabular}

Figure 12. NEPA Potential Risk Analyses Mapped onto Risk Domain $($ Blank $=$ no data $;$ Light $=$ some data $;$ Dark $=$ significant data $)$ 


\begin{tabular}{|c|c|c|c|c|}
\hline \multicolumn{5}{|c|}{$\begin{array}{l}\text { HEDR } \\
\text { - Highly specific radioisotope/human health data } \\
\text { - Addresses radioistopes only } \\
\text { - Very limited exposure pathways and exposure window }\end{array}$} \\
\hline $\begin{array}{l}\text { Excess } \\
\text { Non-eancer } \\
\text { Hazard to } \\
\text { Affected } \\
\text { Population }\end{array}$ & $\begin{array}{c}\text { Exceed } \\
\text { Exposure } \\
\text { and } \\
\text { Dose Limits }\end{array}$ & $\begin{array}{c}\text { Species } \\
\text { Abundance } \\
\text { and } \\
\text { Diversity }\end{array}$ & $\begin{array}{l}\text { Religious/ } \\
\text { Cultural } \\
\text { Area } \\
\text { Degraded }\end{array}$ & $\begin{array}{c}\text { Industrial } \\
\text { Commercial }\end{array}$ \\
\hline $\begin{array}{l}\text { Excess } \\
\text { Cancersin } \\
\text { Affected } \\
\text { populition }\end{array}$ & $\begin{array}{l}\text { Injuries } \\
\text { and } \\
\text { Off-Normal } \\
\text { Events }\end{array}$ & $\begin{array}{c}\text { Habitat } \\
\text { Destruction } \\
\text { or } \\
\text { Degradation }\end{array}$ & $\begin{array}{l}\text { R/C Sites } \\
\text { Disturbed }\end{array}$ & Agricultural \\
\hline MEt & $\begin{array}{l}\text { Worker } \\
\text { Fatalities }\end{array}$ & $\begin{array}{l}\text { Reduction } \\
\text { in } \\
\text { Ecosystem } \\
\text { Function }\end{array}$ & $\begin{array}{c}R / C \\
\text { Resource } \\
\text { Availability }\end{array}$ & Recreational \\
\hline $\begin{array}{c}\text { Public } \\
\text { Health } \\
\text { Risk }\end{array}$ & $\begin{array}{l}\text { Occup. } \\
\text { Health } \\
\text { Risk }\end{array}$ & $\begin{array}{l}\text { Ecological } \\
\text { Risk }\end{array}$ & $\begin{array}{c}\text { Cultural/ } \\
\text { Religious } \\
\text { Risk }\end{array}$ & $\begin{array}{l}\text { Socio- } \\
\text { Economic } \\
\text { Risk }\end{array}$ \\
\hline
\end{tabular}

Figure 13. HEDR Risk Results Mapped onto Risk Domain $($ Blank $=$ no data $;$ Light $=$ some data $;$ Dark $=$ significant data $)$

\begin{tabular}{|c|c|c|c|c|}
\hline \multicolumn{5}{|c|}{$\begin{array}{l}\text { SARS } \\
\text { - Individual failure event analyses of operating facilities } \\
\text { - No aggregation } \\
\text { - Incompatible with standard RA } \\
\text { - Almost entirely radiation and dose based }\end{array}$} \\
\hline $\begin{array}{c}\text { Excess } \\
\text { Non-Cancer } \\
\text { Hazard to } \\
\text { Aftected } \\
\text { Population }\end{array}$ & 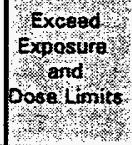 & $\begin{array}{c}\text { Species } \\
\text { Abundance } \\
\text { and } \\
\text { Diversity }\end{array}$ & $\begin{array}{l}\text { Religious/ } \\
\text { Cultural } \\
\text { Area } \\
\text { Degraded }\end{array}$ & $\begin{array}{l}\text { Industrial } \\
\text { Commercial }\end{array}$ \\
\hline $\begin{array}{c}\text { Excess } \\
\text { Cancers in } \\
\text { Affected } \\
\text { Population }\end{array}$ & B. & $\begin{array}{c}\text { Habitat } \\
\text { Destruction } \\
\text { or } \\
\text { Degradation }\end{array}$ & $\begin{array}{l}\text { R/C Sites } \\
\text { Disturbed }\end{array}$ & Agriculturat \\
\hline $\begin{array}{c}\text { MEI } \\
\text { Cancers }\end{array}$ & $\begin{array}{l}\text { Worker } \\
\text { Fatalities }\end{array}$ & $\begin{array}{l}\text { Reduction } \\
\text { in } \\
\text { Ecosystem } \\
\text { Function }\end{array}$ & $\begin{array}{c}\text { R/C } \\
\text { Resource } \\
\text { Availability }\end{array}$ & Recreational \\
\hline $\begin{array}{c}\text { Public } \\
\text { Health } \\
\text { Pisk }\end{array}$ & $\begin{array}{c}\text { Occup. } \\
\text { Health } \\
\text { Risk }\end{array}$ & $\begin{array}{l}\text { Ecological } \\
\text { Risk }\end{array}$ & $\begin{array}{l}\text { Culturall } \\
\text { Religious } \\
\text { Risk }\end{array}$ & $\begin{array}{l}\text { Socio- } \\
\text { Economic } \\
\text { fisk }\end{array}$ \\
\hline
\end{tabular}

Figure 14. Representative SARs Risk Data Mapped onto Risk Domain (Blank $=$ no data $;$ Light $=$ some data $;$ Dark $=$ significant data $)$ 


\section{Gap Analysis}

The mapping of risk information sets shows the following gaps and inconsistencies:

- Significant risk categories of concern are either not addressed by regulatory compliance efforts and other programs or are addressed only in minor ways.

- Risk information is produced by different methodologies based on different assumptions about time, space, and other variables, and is expressed in different metrics (e.g., dose | disease | injury | natural resource destruction). As a result, risk-assessment data for operable units and other Site activities cannot be summed together to obtain cumulative estimates of risk at key receptor locations.

- Large programs, such as CERCLA remediation, do not provide holistic prospective risk estimates for conduct of the entire program over the next 30 years.

- CERCLA Operable Unit Risk Assessments, for example, will be conducted individually over a long period of time.

- Geographical scope is different for different compliance activities; i.e., topographical risk assessment areas are not designed with reciprocal boundaries.

- No regulatory mechanism provides for integration of risk information into a site-wide picture:

- no risk basis for technology choices, hazard ranking, and resource allocation

- no basis for showing site-wide risk reduction from start to finish

- no basis for taking credit for site-wide risk reductions or "offsetting" risk reductions in other activities

- no basis for demonstrating compliance with site-wide aggregate dose limits or other risk guidelines. 


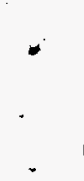




\subsection{Conclusions and Recommendations}

Effective decision making at Hanford requires allocation of resources based on an understanding of the hazards and impacts associated with alternative actions. This understanding must be

- Shared by those major stakeholders who through political power or legal/administrative avenues can prevent implementation of a particular decision

- Clearly and convincingly communicable to DOE-HQ, Congress, and taxpayers

- Integrated into a process that is perceived as accessible, responsive, and fair by all of the above stakeholders.

Effective decision making at Hanford, therefore, requires the risk information described below.

\section{Hanford Site Risk Information Needs}

1. Risk data from all regulatory programs and other projects will need to be integrated into a site-wide picture in order to provide a holistic basis for establishing priorities and supporting allocation of resources.

- The site-wide risk picture will show where the hazards are and how resource allocation corresponds to those risks.

- The site-wide risk picture will show overall risk-reduction targets and the risk reductions achieved across the Site.

- The site-wide risk picture will demonstrate that cleanup decisions have been made on a riskinformed basis, even if some final decisions are driven primarily by non-risk considerations.

2. Hanford decisions need useful site-wide risk estimates for all of the major programs/projects on the Site soon enough to support major prioritization and resource-allocation decisions.

- These risk estimates can initially consist of qualitative interim risk data organized to provide a "gross risk picture" of Hanford.

- These risk estimates must permit comparative evaluation across risk categories and different programs. 
- A cross-cutting risk picture should be produced in time for the 1996 TPA negotiations, and the site-wide picture should be aggressively developed to support crucial decision making in the next three- to five-year time frame.

3. It is necessary to supplement the risk information that will be developed via regulatory compliance efforts in order to consider the appropriate range of risks.

- Some additional risk information will be needed in each of the risk categories.

- Significant supplemental information will be needed in the categories of ecological risk, cultural-religious risk, and socio-economic risk.

4. In order to make the highest and best use of risk data that has been, and will be, produced by existing regulatory compliance and other programs, it is necessary to reconcile heterogeneous data into common metrics.

- Site decision making could be materially aided even by digestion and interpretation of heterogeneous data at a high enough level to support qualitative "side-by-side" evaluation.

5. Early first-order risk estimates need to be developed for activities across the Site in order to support the determination of data quality objectives (DQOs) for additional risk assessments on those projects and programs. It is imporiant to develop risk information robust enough to support good decisions but to avoid wasting resources on unnecessary risk information.

- DQOs for any given project or program can be determined only by examining the particular problem in the context of the Site activities as a whole; risk aspects associated with other activities may eliminate the need to conduct additional risk assessment on certain problems, and may highlight the need for additional analysis of others.

6. Risk must be evaluated across Site programs on an ongoing basis.

- It is necessary to validate risk predictions over the project life-cycle, and provide an actual risk basis for programmatic redirection if actual risks exceed predicted or acceptable levels.

- It is necessary to demonstrate site-wide compliance with exposure limits and other risk limits at any given time.

7. A uniform approach to EIS development and other compliance activities is needed to assure the best fit of risk data from different sources, and to assure the highest achievable level of geographical, subject matter, and methodological complementarity among all such activities. 
- This effort to achieve "best-fit" should be coordinated by a program that has an overall view of all of the compliance activities across the Site.

- This effort should involve early and aggressive development of a Site "template" to support the best possible design of various compliance activities that will be undertaken over a long time period.

8. Innovative methods of risk characterization are needed in all risk categories.

- Public health risk assessment should take into account pathways of exposure associated with subsistence lifestyles and other exposure scenarios that may be particular to the Hanford Site.

- Occupational health risks need to be converted to metrics that permit comparison to public risk.

- Ecological, Cultural-Religious, and Socio-Economic risk assessment are all emerging disciplines; great need exists to characterize risks and impacts in these categories in a way that makes sense to stakeholders and decision makers early enough to support a good RBDM process.

9. Stakeholders should be involved in the entire process of targeting, gathering, and processing risk information. If this is accomplished on a site-wide basis, stakeholders will be far more likely to accept risk-based determinations at all levels.

- Aggressive stakeholder involvement will support the identification and production of risk measures that are recognized and endorsed by these stakeholders when decisions are made.

- Increased trust and confidence in Site management may very well result in greater acceptance of the technical data and conclusions offered to the stakeholders on risk and other matters. 
Appendix A

\author{
Hanford Strategic Plan Goals - \\ Hanford Strategic Plan Supplement \\ October 1994
}




\section{Appendix A}

\section{Hanford Strategic Plan Goals - Hanford Strategic Plan Supplement October 1994}

Goal 1: Manage and Reduce Hazards

Goal: $1.0 \quad$ We will reduce the known hazards in our system while improving the quality of our hazard assessments to guide future decisions on risk mitigation.

Goal Champion: T. R. Sheridan

Strategy 1.1 Aggressively address mitigation of known high-hazard situations at tanks, Plutonium Finishing Plant (PFP), and spent nuclear fuel at K-Basins.

Strategy 1.2 Establish and implement a comprehensive river protection and groundwater management strategy for the Site.

Strategy 1.3 Improve the use and quality of risk-assessment information to provide a clear, comprehensive, defensible, and consistent basis for identifying and understanding the real hazards in our system.

Strategy 1.4 Update safety assessments for all moderate- and high-hazard facilities.

Goal 2: Enhance Worker Safety and Health

Goal: $2.0 \quad$ We will enhance the safety and health of Hanford workers.

Goal Champion: R. P. Saget

Strategy 2.1: Implement the principles of OSHA's Safety and Health Management Guidelines (Voluntary Protection Program):

- Management commitment - Hazard prevention and control

- Employee involvement - Safety and health training

- Work Site Analysis

Strategy 2.2: Implement programs that will result in real improvements in worker safety and health. 


\section{Goal 4: Manage Cleanup as a Project}

Goal: $4.0 \quad$ We will manage the Hanford cleanup as a project by consistently applying project management principles to reach the desired endstate as quickly and cost effectively as possible while considering risks and benefits to the public, the workers, and the environment.

Goal Champion: L. C. Williams

Strategy 4.1 Establish a Hanford Cleanup Project that integrates all Site-wide cleanup activity.

Strategy $4.2 \quad$ Conduct cleanup using, project management principles.

1. Defining and agreeing on the scope of work using proven methods such as systems engineering and risk analysis.

2. Organizing to accomplish the work.

3. Providing adequate resources.

4. Performing the required work on time and within budget.

Strategy 4.3 Improve cost effectiveness and management efficiency by implementing a coordinated set of performance-improvement initiatives.

Goal 6: Improve Decision-Making Process

Goal: 6.0

We will have effective decision making across the Hanford Site that balances decision quality, acceptance of the decision by the public, and timeliness of the decision.

Goal Champion: R. D. Izatt

Strategy 6.1 Develop and implement a structured methodology for decision making that identifies

- The decision to be made

- Who should make the decision

- When the decision is required

- Consideration for public involvement

- Data/information required for the decision.

Strategy 6.2 Develop and manage an infrastructure that supplies consistent information throughout the decision process.

Strategy 6.3 Publicize/celebrate decisions and support decision makers when informed decisions are challenged. 
Goal 7: Science and Technology

Goal: 7.0 We will be leaders in providing science and technology that enhances Hanford cleanup, improves U.S. competitiveness, and supports the regional, national, and international need to balance economic growth and environmental responsibility.

Goal Champion: R. M. Rosselli

Strategy 7.1 Directly link Science and Technology (S\&T) efforts to specific cleanup needs and engage our regulators, stakeholders, and potential technology users in the technology development process.

Strategy 7.2 Support regional, national, and international S\&T needs; sustain our national multi-program laboratory; enhance its competitiveness and responsiveness to needs; and build partnerships with other S\&T communities.

Strategy 7.3 Focus attention, resources, and action on Hanford's S\&T mission element and its role in balancing economic growth and environmental responsibility.

Goal 8: Build Partnerships

Goal: $8.0 \quad$ We will establish positive working relationships that will build confidence and enhance trust in Hanford.

Goal Champion: K. K. Randolph

Strategy 8.1 Create and maintain decision-driven public involvement that includes the budget process, ensures stakeholder participation before key decisions are made, and serves as a model for the DOE system (e.g., the Hanford Advisory Board).

Strategy 8.2 Consult with Native American tribes as sovereign nations to ensure that tribal rights and values relative to Hanford are incorporated into Hanford decision making.

Strategy 8.3 Develop a more open and accessible communication system that provides prompt responses to public information requests and actively reaches out to the public and media to share information.

Strategy 8.4 Enhance employee understanding and support of Hanford's mission, values, and strategic objectives through expanded site-wide communications, particularly face-to-face communications with management. 
Appendix B

Minimum Domain of Hanford Risk Information Needs Primary Risk Categories and Salient Parameters 


\section{Appendix B}

\section{Minimum Domain of Hanford Risk Information Needs Primary Risk Categories and Salient Parameters}

\section{Public Health}

- Excess individual lifetime cancer risk to the MEI for all contaminants through all reasonable exposure pathways

- Cumulative excess cancers in impacted populations for all contaminants through all reasonable exposure pathways, integrated over a designated time frame

- Risk of exceeding the non-cancer Hazard Quotient for one contaminant or the additive Hazard Index for multiple contaminants

2. Occupational Health and Safety

- Risk of exceeding OSHA/ICRP limits for ceiling or daily exposures, annual dose, and/or lifetime dose

- Risk of exceeding a defined number of reportable injuries of various severities and risk of exceeding a defined number of off-normal operating events

- Risk of a worker fatality(ies) due to acute exposure and or accidents

\section{Ecological Risk}

- Diversity (\# of species/area) and abundance (\# of individuals/area) of terrestrial and aquatic species

- Area of mature native habitat and potential reduction of service value

- General ecosystem function, including contaminant levels in air, soil, and water, as well as cover, water use partitioning, amount of fauna supported, and promotion of noxious weed propagation

B. 1 


\section{Cultural/Religious}

- Number and/or size of areas of religious/cultural importance subject to restricted use and/or encroachment and/or to aesthetic or physical disturbance or degradation

- Number of culturally significant sites, such as burial sites, that might or would be disturbed or contaminated

- Decreased availability, whether due to restrictions, disturbance, or destruction, of culturally significant biotic resources, such as medicinal roots or ceremonial plants

\section{Socio-economic}

- Impacts on subsistence and recreational value, including shoreline access and development

- Impacts on agricultural value, including contingent valuation of externalities

- Impacts on value of industrial-commercial uses 


\section{Appendix C}

Major Regulatory Compliance and Other Programmatic Risk Information Sources 


\section{Appendix C}

\section{Major Regulatory Compliance and Other Programmatic Risk Information Sources}

\section{Major Regulatory Compliance Activities}

The major regulatory compliance activities that involve or require the generation of significant risk information are conducted under the following major environmental laws:

- Atomic Energy Act

- Occupational Safety and Health Act

- Resource Conservation and Recovery Act

- Comprehensive Environmental Response, Compensation and Liability Act

- National Environmental Policy Act

A summary of the risk information required by each of the major acts follows.

\section{Atomic Energy Act (AEA) (42 U.S.C. 2011 et seq.)}

AEA was enacted for national security and safe development of atomic energy. It confers upon DOE the general obligation to protect the health and safety of the public.

\section{Domain}

All activities undertaken involving DOE's development, use, and control of nuclear energy and nuclear materials.

Risk Data Required for Compliance

The AEA requires no specific risk information. 
Issues

The authority to develop atomic military power and promote peaceful uses of atomic energy was conferred upon DOE's predecessor with the acute recognition that nuclear materials posed a unique danger to public health and safety. DOE is responsible for protecting the public welfare in its management and disposition of nuclear material and wastes and in its management of the Hanford Site as a whole. This means that any specific waste management or cleanup activity must be evaluated in terms of the aggregate threat to the public welfare associated with the entire Hanford facility. Thus, to the degree that it contributes to the overall site-wide hazard to public health and safety, no single operation or slice of time may be considered in isolation.

\section{Occupational Safety and Health Act (OSHA) (29 U.S.C. 651 et seq.)}

OSHA is the basic worker protection law that requires employers to protect the health and safety of employees in the work place through the implementation of detailed safety procedures and equipment, training and education, medical evaluation and monitoring, and workplace evaluation, including compliance with occupational exposure limits for chemical and physical agents.

\section{Domain}

Health and safety hazards to employees in the workplace.

\section{Risk Data Required for Compliance}

OSHA has a prevention and compliance orientation; that is, it requires conformance to specific procedural and safety equipment requirements and the assurance that exposure limits for toxic substances are not exceeded. The exposure limits themselves are fundamentally risk-based, and compliance requires the field monitoring of contaminant levels or other measures to prevent overexposure. However, the employer is not required by OSHA to perform risk analyses on particular activities to determine the risk of harm to workers and/or the costs of preventing those risks. (Cost-benefit analyses may, in some cases, be considered in the choice of exposure control alternatives.)

\section{Issues}

The human health risk assumptions underlying OSHA chemical exposure limits are available, and may be useful in comparative risk assessments for activities among different categories of risk. However, the specific rationale for OSHA exposure limits for different chemicals varies greatly from one toxic agent to the next, based on exposure issues particular to the occupational setting, and therefore such exposure limits cannot be directly related to public health risks without complex and systematic analysis. 


\section{Resource Conservation and Recovery Act (RCRA), as Amended by the Hazardous and Solid Waste Amendments (42 U.S.C. 6901 et seq.)}

RCRA was enacted to protect public health and the environment through cradle-to-grave regulation of hazardous waste and waste management practices. Worker training and protection are also significant parts of the RCRA regulatory program. RCRA is more focused on industrial facilities that manage wastes, so RCRA's role in protection against ecological impacts or environmental impacts beyond facility boundaries might be considered less than CERCLA or NEPA.

\section{Domain}

Hazardous and mixed waste management, including transportation, storage, and disposal.

\section{Risk Data Required for Compliance}

RCRA does not require determinations of risk to the environment and human health and safety. It does establish operating standards for permitted facilities, which are subject to other legal requirements regarding emissions and effluents. Corrective action is strongly oriented toward protection of groundwater, and cleanup levels are cleanup to background levels or to specific contaminant concentrations at a point of compliance somewhere in proximity to the specific hazardous/mixed waste site. Alternative concentration levels may theoretically be negotiated with the regulators.

\section{Issues}

Risk-based alternative concentration levels (ACLs) are difficult to approve, and may depend for their availability upon persuasive risk analyses not required by RCRA.

\section{Comprehensive Environmental Response, Compensation, and Liability Act (CERCLA) as Amended by the Superfund Amendments and Reauthorization Act (SARA) (42 U.S.C. 9601 et seq.)}

CERCLA provides for cleanup of hazardous substances, including radionuclides, to the environment. The Hanford Site is on the CERCLA National Priority List, and much of the Site is being cleaned up under the authority of this Act. Section 121 of CERCLA requires that remedial actions attain a level of cleanup that "at a minimum assures protection of human health and the environment."

\section{Domain}

Cleanup of hazardous and radioactive substances from soil, surface water, and groundwater from past practice units. 


\section{Risk Data Required for Compliance}

CERCLA explicitly requires a balancing of factors in selecting a remediation alternative that protects the environment and human health and safety. This balancing act necessitates extensive risk analysis of the hazards posed by the source term, the fate and transport of contaminants, and exposures to workers and the public.

CERCLA requires site characterization (source term or "hazard identification"), exposure assessment (transport of contaminants to the receptor and calculating the receptor's doses through appropriate pathways of exposure), toxicity assessinent (how toxic is each contaminant, taken from EPA databases) and risk characterization (what does it mean for the receptor; how should uncertainty be analyzed). Beyond this, there is considerable flexibility with respect to the pathways chosen for analysis, the transport codes, the intake factors used (defaults are provided), and the level of precision (screening, qualitative, or quantitative). Risk Assessment Guidance (RAGS) focuses on present-generation individual excess lifetime cancer risk and present-generation exceedance of non-cancer reference doses. While suggestions are made for population risks, identification of critical groups and other refinements, there is no prescription for exactly how to do this, and individual risk assessments are tailored to the circumstance.

CERCLA also deals with EcoRisk, and manuals are being developed, but an ecological RAGS has yet to be published. In addition, CERCLA deals with worker and public exposures during remediation alternatives.

\section{Issues}

CERCLA only requires that this comparative risk analysis be conducted for the contaminated unit that is actually being cleaned up by the specific action. Hanford has 78 operable units, about half of which are scheduled to be cleaned up under CERCLA. The risk analyses that will be undertaken pursuant to CERCLA will be performed independently for each operable unit over a long time frame. This means that the aggregate impacts of the entire Hanford CERCLA cleanup will emerge incrementally over a period of decades. CERCLA does not require aggregate analysis of all CERCLA geographically proximate cleanup sites, nor does it require integration of the exposures and risks associated with the operable unit cleanups with the overall hazards posed by other activities on the Hanford Site. Numerous other waste management and cleanup activities will be occurring simultaneously across the Site over the coming decades. Not only would this "segmentation" fail to portray the aggregate risk to human health and safety on and off the site, but it would result in understatement of the ecological impacts, the proper assessment of which depend upon holistic, long-term evaluation of complex biotic systems. 


\section{National Environmental Policy Act (NEPA) (42 U.S.C. 4321 et seq.)}

NEPA was enacted to ensure appropriate environmental reviews of major federal actions with potential for impact on the environment. NEPA can address many types of risk, depending on the scope of the actions considered, but it places relatively less emphasis on public health and occupation risks.

NEPA requires federal agencies to write an environmental impact statement (EIS) for major federal actions significantly affecting the quality of the human environment. The EIS must treat all alternatives in substantial detail and, to the degree possible, with the same level of detail.

\section{Domain}

Adverse impacts on the environment, including human health and safety, socioeconomic, ecological, aesthetic impacts. Cumulative impacts must be addressed (see Figure C.1).

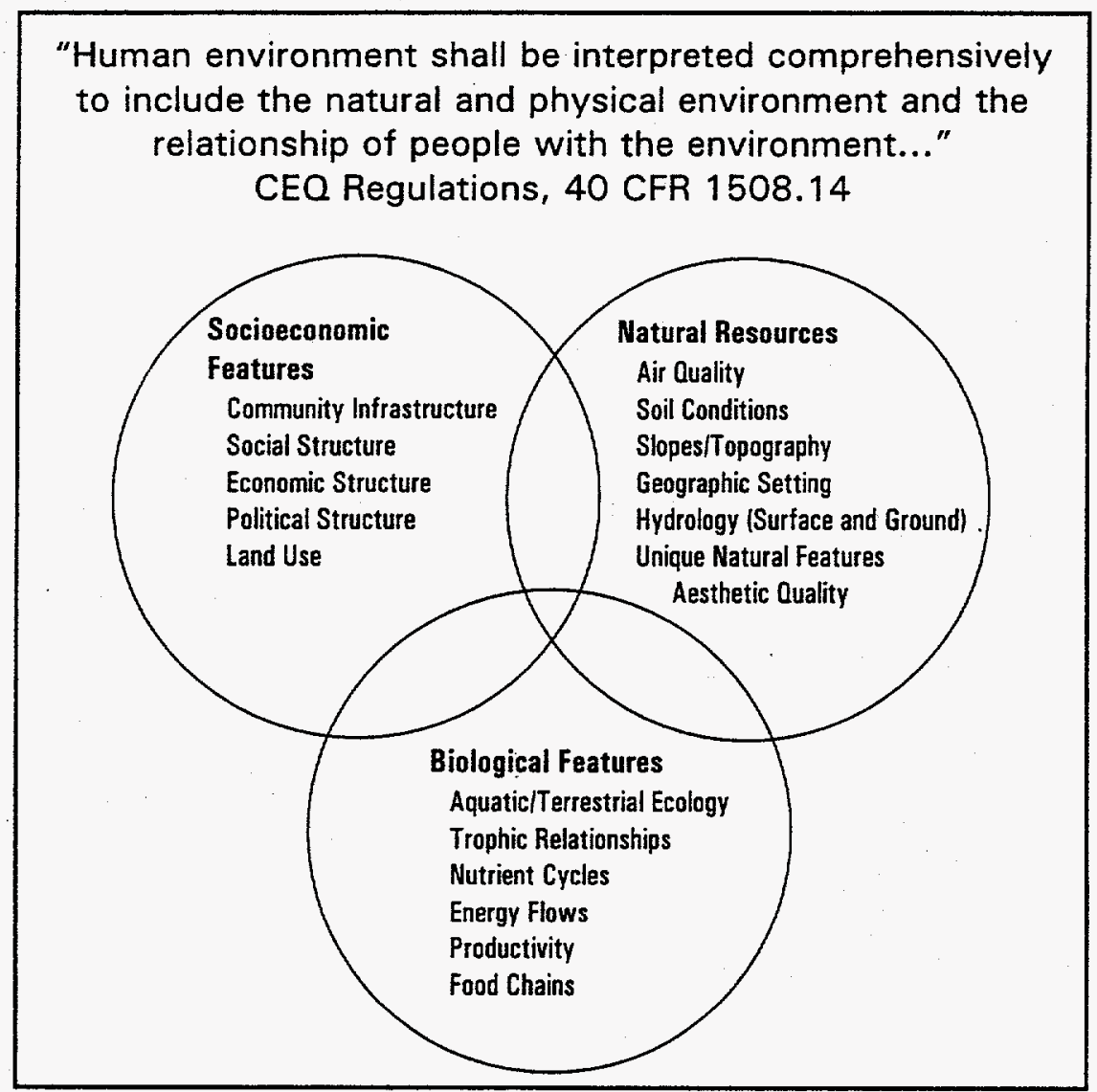

Figure C.1. NEPA Broadly Defines the Human Environment (Source: Steven Konkel) 


\section{Risk Data Required for Compliance}

Effective compliance with NEPA requirements for EISs requires characterization of all of the above-noted impacts by methods that will support comparison of alternatives and withstand scientific scrutiny. Impact assessment, therefore, is often communicated in terms of risk and placed in perspective based upon actuarial or other risk data. Human health impacts, particularly, are typically characterized in terms of potential excess incidence of cancers and/or other morbidity/mortality dimensions. Worker health and safety risks are also typically characterized. The EIS, then, can potentially be an excellent vehicle for holistic risk assessment.

\section{Issues}

NEPA, its implementing regulations, and the voluminous guidance documents for production of EISs, do not provide a uniform protocol for the production of risk data across the environmental impact categories. Each EIS is therefore unique, and the relative comparability of some human health risk data is not paralleled in the areas of ecological, cultural, socioeconomic, or other categories. Even in the human health impacts arena, there is much variability in the temporal and spatial dimensions of risk quantification. Numerous EISs have been written for the Hanford Site, and many others are already planned or anticipated. Hanford EISs are not developed based upon a common iemplate that provides for the production of risk data based on common assumptions, methodologies, or metrics. Therefore, those risk data that have been or will be produced in various activity-specific EISs are not directly comparable, nor are they in a form that automatically supports consolidation that portrays site-wide risks. In addition, EIS analysis is strictly predictive; there is no mechanism in NEPA to assure ongoing impact assessment in a uniform way in order to evaluate aggregate or cumulative impacts during operation or after completion of the major action. Determination of scope and boundaries within and among the several major EISs has been done on an ad hoc basis.

This variability of content, scope, and methodology strongly supports the need for an analytic framework that makes the best use of available EIS risk data and integrates those data into a site-wide view of risk that will support comparison of risks among various categories of risk and among various alternative actions. In addition, intelligent site-wide decision making depends upon a holistic risk framework that provides guidance to the EIS process to assure maximum compatibility and "scope reciprocity" among Hanford EISs, and which assures site-wide aggregation and description of risks and impacts across all programs during and after commencement of activities.

\section{Other Major Risk Data-Generating Activities}

\section{Hanford Dose Reconstruction Project}

This project provided a means for people to estimate their individual radiation doses from past Hanford releases (1944-1988) based on their age, sex, place of residence, and diet. Results are presented as median and ranges. Selected exposure pathways and 6 of the most important radionuclides 
(especially I-131 particulates) were considered. Cows' milk was most important for air releases (human breast milk is not mentioned), and fish consumption for river releases. This project may provide historical information and generic uptake, bioconcentration, and intake data that are useful to prospective assessments.

\section{Safety Analysis Reports}

SARs are analyses of SAFETY, i.e., they are done to demonstrate that safety measures have been applied at specific process points to reduce the probability of release events, so that the combination of probability and dose falls within NRC guidelines. They look at individual events/sources rather than facility-wide occurrences, do not aggregate, and express results only in terms of dose. Comparison to standard risk assessment results is difficult to impossible. SARs do not consider what would happen if events go to completion, nor do they consider any multiple-source roll-ups. SARs deal very poorly with chemical hazards. SAR results could not be easily used (or perhaps even used at all) in standard risk assessments, nor can they practicably be used as a foundation for estimations of annual site-wide dose. SARs do not provide the necessary data to support allocation of exposure-limit quotas in order to assure that facilities operations and remediation activities combined fall within aggregate Site exposure limits. 
Appendix D

Risk Gap Matrix - Laws and Programs 


\section{Appendix D}

\section{Risk Gap Matrix - Laws and Programs}

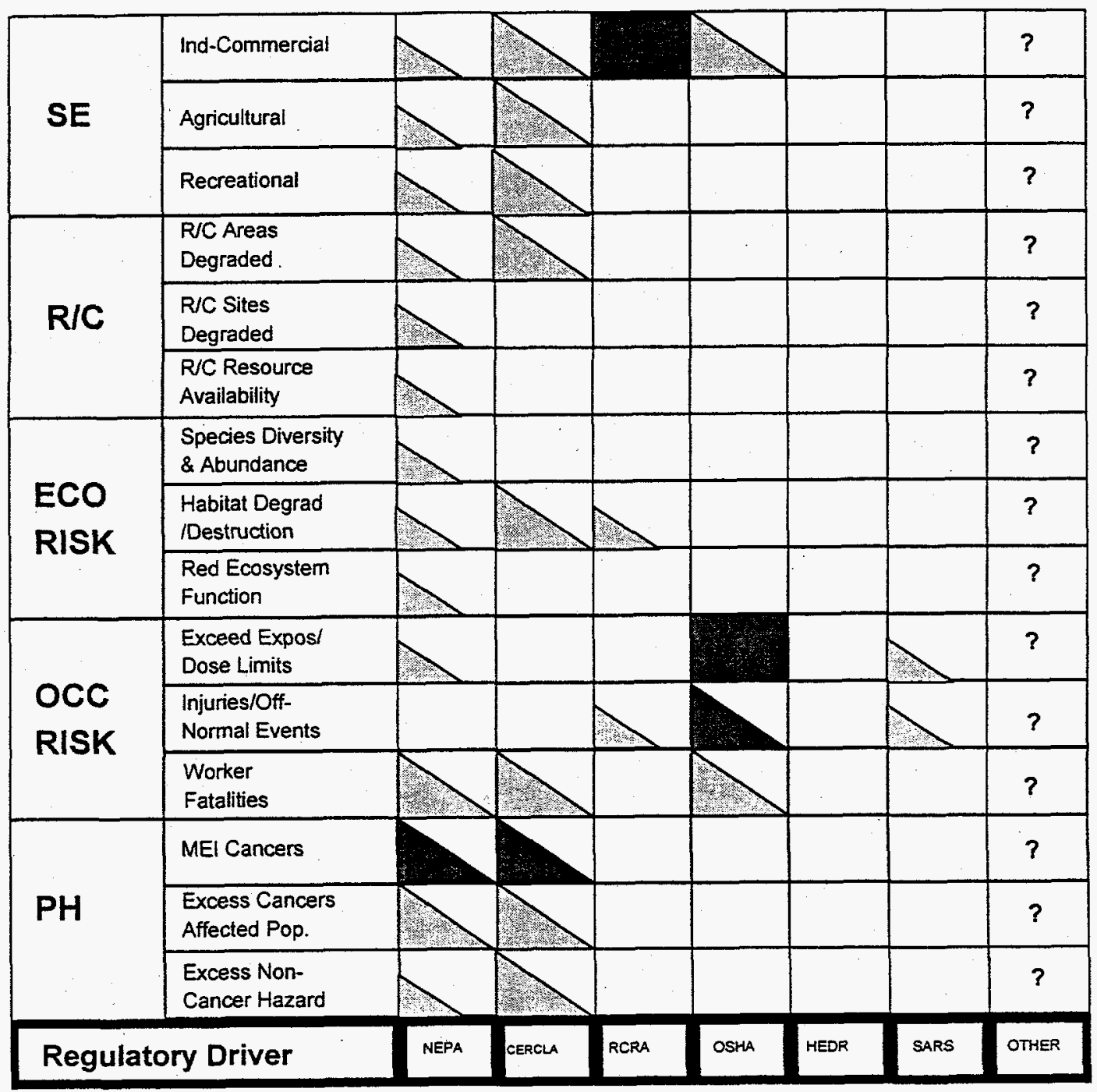

\footnotetext{
- Good Coverage, good data quality.

6. - Good Coverage, inadequate data quality.

- Some Coverage, good data quality.

- Some Coverage, inadequate data quality.

- Minor Coverage, good data quality.

- Minor Coverage, inadequate data quality.
} 


\section{Distribution}

Offsite

Judith Bradbury

Battelle Washington Operations

Bob Hegner

Battelle Washington Operations

Richard Lovely

Battelle Seattle Research Center

Bechtel Hanford Inc.

Merl Lauterbach

H4-91

Roger Ovink

H4-92

Tom Wintczak

H4-92

\section{U.S. Department of Energy - Richland Operations} (DOE/RL)

$\begin{array}{ll}\text { Suzanne Clarke } & \text { A5-52 } \\ \text { Thomas Ferns } & \text { H4-83 } \\ \text { Carolyn Haass } & \text { S7-51 } \\ \text { Steve Hwang } & \text { A5-18 } \\ \text { Jim Kautzky } & \text { A5-58 } \\ \text { Paul Krupin } & \text { A5-15 } \\ \text { Lloyd Piper } & \text { R3-78 } \\ \text { Theo Schmeeckle } & \text { G3-18 }\end{array}$

Environmental Protection Agency (EPA)

Larry Gadbois

B5-01

\section{Pacific Nortwest Laboratory (PNL)}

John Abbott

K6-75

Cynthia Abrams

K8-03

Richard Badalemente

K8-21

Gordon Bilyard

$\mathrm{K} 8-03$

K6-84

K8-07

Alan Brothers

K6-80

John Buck

P7-82

Richard Bull

K8-07

Joe Devary
Pacific Northwest Laboratory (PNL)

Pam Doctor

K8-37

Jim Droppo

K6-80

James Dukelow

$\mathrm{K} 8-37$

Paul Ellis

P7-55

Paul Eslinger

K6-77

Bill Farris

K3-54

Kim Fowler

K9-69

Lynn Franklin

K8-07

K9-36

K8-03

K9-70

P7-82

K6-80

K8-37

K9-04

P7-82

K8-07

K8-03

K8-03

K9-33

K3-75

P7-35

K9-41

K8-07

P7-82

K6-77

K7-74

K7-90

K8-03

K3-54

K6-75

K3-56

K9-69

K8-38

K3-54

S7-71

K7-94

K7-97

K3-62

K3-54

K9-09

K3-56

K9-36

P7-79

K8-37

Michael Zentner

PNL Information Release

Office (7)

K1-11 